\title{
Comparison between light and diet food in relation to conventional food through the analyze of labels
}

\author{
Margarete Frutuoso Antunes ${ }^{1}$, Daniela Soares de Oliveira ${ }^{1}$, Rafael Resende Maldonado ${ }^{1,2,}$, \\ ${ }^{1}$ Nutrition Course, Faculdade Municipal Professor Franco Montoro, Mogi Guaçu, Brazil \\ ${ }^{2}$ Food Department, Technical College of Campinas, University of Campinas, Campinas, Brazil
}

\section{Email address:}

margarete.frutuoso@hotmail.com (M. F. Antunes), danielasoares.nutricionista@hotmail.com (D. S. de Oliveira), ratafta@yahoo.com.br (R. R. Maldonado)

\section{To cite this article:}

Margarete Frutuoso Antunes, Daniela Soares de Oliveira, Rafael Resende Maldonado. Comparison between Light and Diet Food in Relation to Conventional Food Through the Analyze of Labels. Journal of Food and Nutrition Sciences. Vol. 2, No. 4, 2014 , pp. $156-161$. doi: $10.11648 /$ j.jfns.20140204.19

\begin{abstract}
The aim of this work was to analyze light and diet food and to compare them with conventional version identifying compliance with the recommendations set by the Brazilian law. Seventy light and diet food were selected. The variation of the amount of nutrients compared to conventional version was calculated. The products were divided into 6 categories (dairy, beverage, starch, sweet, sauce and meat) to systematize the evaluation. The quantity of energy, carbohydrate, sugar, protein, total fat, sodium, fiber and calcium were evaluated according to Brazilian law. Most of products evaluated were in accordance with the law. Only $12.8 \%$ of the products had some problems with the legislation. Some products presented harmful changes for the consumers, such as increased levels of sodium (53\%) and protein (60\%), and reduced fiber content in $70 \%$ of cases. On the other hand, some products presented beneficial changes, such as increase of calcium $(55 \%)$. Furthermore, $51 \%$ of products had a reduction in calorie above $25 \%$ in relation of conventional food (minimum required for light products according to Brazilian law). In relation to total fat, this number increased to $70 \%$. Most of light and diet products were in accordance with the Brazilian law, with reduction of carbohydrates, fats and calories, but there is still a percentage of irregular products with increased in protein and sodium, and reduced in fiber which it may be harmful to the consumer.
\end{abstract}

Keywords: Light Food, Diet Food, Labeling, Health

\section{Introduction}

The process of demographic, epidemiological and nutritional transition has caused changes in the health status of people with a significant increase in non-communicable chronic diseases (NCD)[1]. Chronic diseases, including cardiovascular diseases, diabetes mellitus type 2, obesity, osteoporosis, metabolic syndrome and cancer, are causes of death and morbidity worldwide. Clinical and epidemiological evidence shows that lifestyle and eating habits are the main causal factors of this epidemic [2]. In order to improve the quality of life of individuals in treatment and/or preventing the emergence or worsening of NCDs, food for special purposes called light and diet were created. With the appearance of these products, the correct identification of nutrients on the label has become essential to ensure consume safety [3].
The demand for light and diet products have grown and tend to increase in the coming years. This is due to the increase in concern regarding the diet versus health, which encourages consumption of healthy foods, nutritious, functional and low calorie nutrients that have potential health protection [4]. $20 \%$ of Brazilian housewives are concerned about the health of the family and approximately $35 \%$ of houses consume some kind of light and/or diet product [5].

According to the National Health Surveillance Agency (ANVISA) diet food is intended for restricted diets nutrients, suitable for use in different diets and/or options to meet needs of people in specific metabolic and physiological conditions. Light food presents at least $25 \%$ reduction in calories or certain nutrients compared to conventional version [6].

Labeling is the means by which to establish a channel 
between producers and consumers of food. It is necessary that the information on the labels is accurate and consistent with the reality of purchased products. Among other objectives, the labeling scheme seeks to protect consumers from unfair or unfounded statements that may induce them to errors [7].

The label is the primary way that consumers have to evaluate a food. Since 2001 it has been established in Brazil that all packaged food and beverage should compulsorily submit the following nutritional information: calories, carbohydrates, protein, total fat, saturated fat, cholesterol, dietary fiber, calcium, iron and sodium. The percentage of the daily value (\% DV) and the portion are mandatory. The labels should not contain unnecessary information, such as vegetable oil without cholesterol because vegetable oil has no cholesterol composition [6].

Labels are communicative data between the product and the consumer, and should guide them in purchasing decisions, generating greater market efficiency and consumer welfare. Therefore, even though a mandatory labeling item, this fact does not guarantee that the nutrient composition indicated on the label is properly correct, which could induce inappropriate consumption and cause damage to the health of the consumer [8].

There is a worldwide trend to reduce the time available for feeding, which leads the search for practicality and convenience in relation to food. Consumers nowadays want foods easy to prepare, with longer shelf life, proper portioning, storage and easy maintenance. Thus, the market for industrial products are on the rise, however much of these products contain high levels of sodium, fat, sugar and others. Many studies have shown that excessive consumption of processed food can cause growth of chronic diseases in the population $[9,10]$.

Thus, the aim of this work was to evaluate labels of light and diet products comparing them with food in the conventional version and identifying compliance with the mandatory recommendations of the labeling imposed by the National Health Surveillance Agency (ANVISA) in Brazil.

\section{Material and Methods}

70 foods classified as light $(80 \%)$ or diet $(20 \%)$ and their conventional versions were selected. The products were chosen randomly and according to availability in supermarkets in the region of Mogi Mirim, in the countryside of Brazil.

The labels were photographed and nutritional data were entered into a data spreadsheet program Microsoft Excel 2007. It was calculated the variation of the amount of nutrients from light and diet products over conventional version. This calculation was conducted through the values expressed on the labels and when necessary with the aid Brazilian Table of Food Composition [11].

To evaluate reduction or increase of nutrients in light or diet foods over conventional version (required item under Brazilian law), it was made the division into three groups: products with reduction above $25 \%$; products with reduction bellow $25 \%$ and products with increased in nutrient, and to better organize the data analysis, the products were divided into 06 categories: dairy, beverage, starch, sweet, sauce and meat. Mandatory labeling information (energy, carbohydrates, sugar, protein, total fat, sodium, fiber and calcium) were evaluated.

\section{Results}

The 70 light or diet products evaluated were separated into 16 in dairy product, 9 in beverage, 22 in starch, 15 in sweet, 5 in sauce and 3 in meat, as Figure 1 shows. In dairy product were evaluated yogurt, margarine, requeijão, coconut milk and milk cream. In beverage were evaluated soft drink, fruit juice and tea. In starch were evaluated bread, popcorn, cake, toast, cracker, oatmeal, cereal bar, breakfast cereal, pasta pizza, and noodle. In candy were included chocolate bar, chocolate powder, guava candy, jelly, jam, peanut candy and instant pudding. In sauce were included mayonnaise and tomato sauce and finally, in meat category were evaluated sausage and canned tuna.

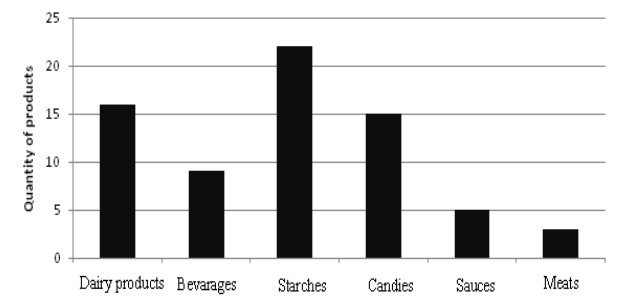

Figure 1. Number of products analyzed by category.

In relation to total product evaluated just $9(12.8 \%)$ were in non-compliance with the legislation. 4 products $(5.7 \%)$ had inconsistence between calorie and composition indicated on the labels; 4 products $(5.7 \%)$ were called light without presenting reduction above or equal to $25 \%$ of any nutrient and one product (1.4\%), called diet, that did not show any reduction in nutrients, and indeed containing sucrose.

To determine whether there was an increase or reduction of nutrients from diet and light products compared to conventional version, they were divided into three groups: foods with reduced above $25 \%$; products with a reduced below $25 \%$ and an increase of food nutrients. Figure 2 shows the results obtained according to this classification.

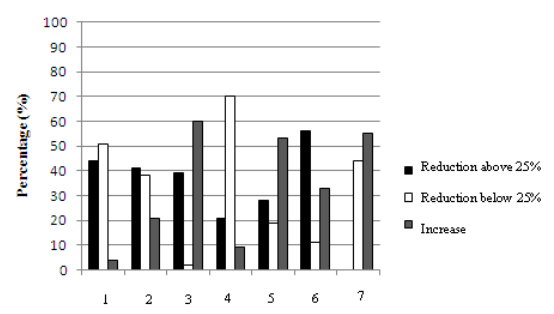

Figure 2. Percentage change in the amount of nutrients in food evaluated ( 1 = calorie; 2 =carbohydrate; 3 =protein; $4=$ total fat; $5=$ Sodium; 6 =fiber; $6=$ Calcium) 
According to figure 2, it is possible to highlight relevant information about the comparison of light and diet food with conventional version. Regarding calorie only $51 \%$ of the products showed a reduction above $25 \%$.

From all products evaluated, only the soft drink "type zero" and Mate Tea diet presented a $100 \%$ of decrease in calorie. Towards jams, the two formulations evaluated were given the name of diet; however, they have sugar from fruit itself. Under Brazilian law, diet products may contain sugar naturally present in fruit, but cannot receive added sugar.

Still on the issue of calorie, in most foods, it mainly comes from carbohydrates and fats. Looking at Figure 2, we note

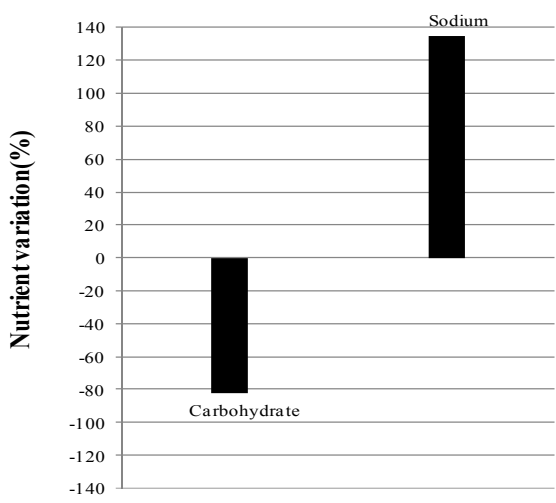

(a) that about $20 \%$ of products in the light version had an increase instead of reducing carbohydrates, which is highly undesirable for the consumer. Due to specific diseases (diabetes, hypertriglyceridemia, etc) or desire of weight loss.

From all the groups studied, carbohydrate reduction was significant only in two groups, beverage and sweet, as seen in Figure 3. In the other hand, the reduction of fat was greater in starch and dairy products, as seen in figure 4 . In relation to fat it was found that about $70 \%$ of the products evaluated had a reduction above $25 \%$ which is desirable by consumers.

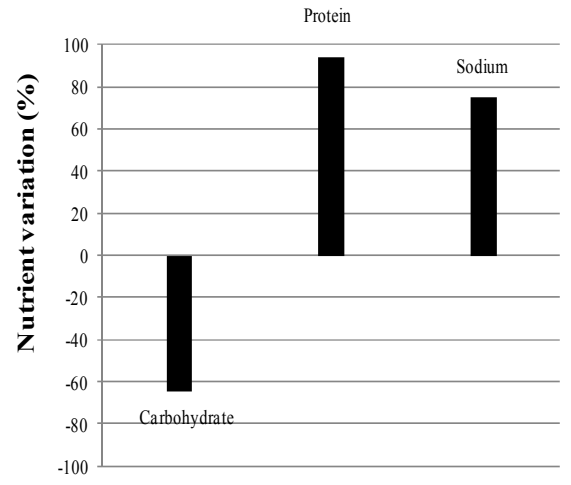

(b)

Figure 3. Percentage of average variation of main nutrients of light and diet versions (a) beverage (b) sweet.

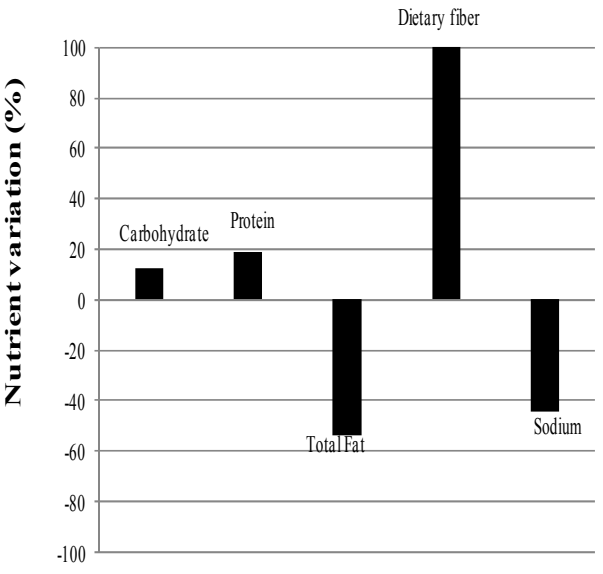

(a)

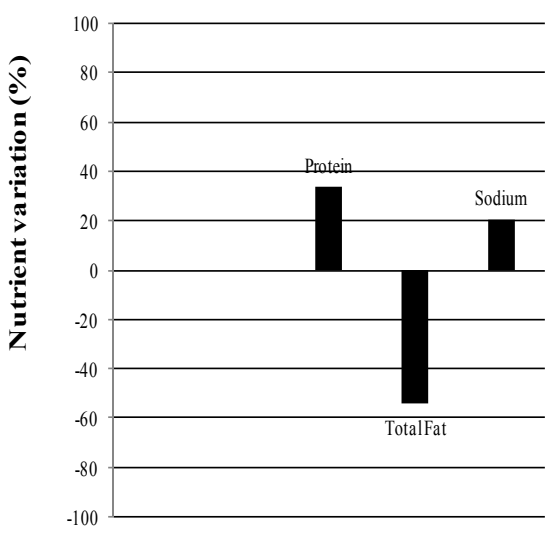

(b)

Figure 4. Percentage of average variation of main nutrients of light and diet versions for (a) starch (b) dairy product.

Regarding to protein, sodium and calcium, it is possible to see an increase of these nutrients on most products. In $60 \%$ of the products there was an increase in protein; in 53\% of the products there was an increase in sodium and in 53\% of the products there was an increase in calcium.

Proteins were considerable increase in sweet, starch and dairy products (Figures 3 and 4) and sodium increased in 4 of the groups evaluated (beverage, sweet, dairy products and sauce). Calcium increase was only significant for the dairy product.

Worrying information relates to reduced fiber in light or diet foods. According to data collected in only $30 \%$ of the products evaluated showed increase of fiber while a reduction in fiber was verified in the other $70 \%$ of the foods evaluated. Considering division by categories chosen in this article, only starch showed a significant increase in fiber in light foods compared to traditional version (Figure 4a). 


\section{Discussion}

Different studies in the literature report that it is common irregularities in the label of most light and diet products. One study evaluated 43 products light and diet and irregularities appeared in $55.5 \%$ of diet products and $31.25 \%$ of light products [12]; in other study 27 labels were analyzed and it was found $85.2 \%$ of irregularities [13]; in a third study was found $76 \%$ of irregularities in a set of 50 labels evaluated [7].

It is possible to see that the reported data indicate a number of irregularities in the labels much higher than those found in this study (12.8\%). Due to our work evaluated just information towards the classification. The other works analyzed all the information in the label.

There is a common sense that diet products do not contribute to get fat and they can be consumed in any amount [14]. However, in some cases, such as chocolate diet, there is no added sugar in the composition, but the fat content is higher than in the traditional version, which makes this food indicated for individuals with diabetes but not for people seeking weight loss. Considering this information it can be said that a person seeking for weight loss and is not aware the concept of diet food can consume it improperly [15].

In other study results highlighted that a high percentage of normal weight girls consume light and diet food to lose more weight and reach the ideal body image. In this case, the lack of correct information about light and diet food can lead to nutritional deficiencies and provoke certain diseases [16].

It was observed during the evaluation of light and diet products that in many cases the reduction of calories was obtained through the reduction of minority components of the formulation. This fact is adequate towards Brazilian law, but it does not meet the consumer expectations.

It was found, for example, in formulations of light bread, in which the adaptation to the law was made by reduction of total fat. However, the amount of fat in the formulation is relatively small, which leads to reduction in calorie significantly lower than $25 \%$ (recommended by law), ranging from 0 to $14 \%$ in different brands evaluated.

This conclusion is relevant, since many consumers look for this type of product precisely to reduce calorie intake in order to reduce the weight for health reasons and/ or aesthetics. Most consumers are not attentive to the label information; they often acquire diet or light products with a great expectation of reduction of calories. Due to this many consumers consume higher quantity of these products and instead of losing weight they gain weight [17].

Several studies have demonstrated a lack of knowledge of the population about diet or light products and food labels. One study showed that only $18 \%$ of consumers surveyed agreed to the concept of light food, $27 \%$ said they ate such foods in order to reduce body weight and 15\% reported consuming larger portion of the light food compared to the traditional one [18]. In other study, the term light was mainly associated with low-calorie foods or low fat [19].
Other study showed $35.8 \%$ of respondents consumers read food labels, $53.3 \%$ of the total said they did not understand anything about food labeling; $64.2 \%$ did not know the difference between light and diet and $43.1 \%$ of those interviewed said they have some type of chronic non-communicable disease (NCD), which may cause the incorrect use of these products and can even worsen health problems [20].

A product with reduced calories and nutrients not always means a considerable gain for the consumer. For example, dough of pizza evaluated received light classification due to $68 \%$ reduction in fat. However the fat represents only $5.5 \%$ of the traditional formulation. Thus, a less attentive consumer can imagine that such a product in the light version can ensure a considerable reduction in calorie, which is not true because fat has little importance in this type of food.

On the one hand the increase in nutrients can be beneficial. This is what happens in the case of calcium, which increase intake of this nutrient is beneficial for certain groups of consumers, such as the elderly and women during the menopause as it can help in maintaining bone, preventing osteoporosis. However it should be noted that if there is increased protein and calcium in the same product, calcium absorption may be impaired by the increased amounts of protein, since such excess can stimulate excessive loss of calcium [21]

The increased amount of protein in diets can be interesting in that you want to help maintain muscle mass and strength, provided that this increase is accompanied by physical activity and a professional [22]. On the other hand, excessive protein intake can be a problem for individuals who tend to have kidney problems because the initial phase of the disease is essential that there is a reduction in the intake of protein and potassium, in order not to overload the kidneys [23].

To incorporate many diet or light products in the diet of the population may also contribute to increased blood pressure by excess sodium intake, since this nutrient is increased in 53\% in light or diet products evaluated (Figures 3 and 4).

In relation to sodium, there is vast literature cites that the increase of this nutrient in the diet is very harmful, especially with regarding to increased blood pressure, regardless of age and other factors. In addition it can increase the risk of cardiovascular disease, myocardial infarction, heart failure and progression of renal disease [24].

Regarding the reduction of $70 \%$ of the fibers in the diet and light products evaluated it is not good due to insoluble fibers have a fundamental role in improving intestinal transit and soluble fiber are connected to delay gastric emptying, decreased serum cholesterol and glucose modulation. Furthermore fibers can reduce the risk of some diseases such as obesity, diabetes and cardiovascular [25]. Thus, the use of food in light or diet versions should be monitored in order to avoid significant losses in relation to consumption of dietary 
fiber, since this play an important role in a nutritionally balanced diet.

\section{Conclusion}

The results of this study showed that about $87 \%$ of light and diet products were in accordance with current legislation, but in some cases the changes in the formulations were developed in minor components, which may not bring significant nutritional benefit to the consumer.

Most products evaluated showed reduction of carbohydrates, fat and fiber, and increase protein, sodium and calcium in relation to their conventional versions. It is worth saying that the increase in sodium and reduced fibers are undesirable aspects of nutritional point of view because they bring harm to health.

On the other hand, the reduction of carbohydrates and fat, and increase in calcium can be considered to be nutritionally positive in this type of food; however, the data does not always have shown that reducing carbohydrate and fat occur as high how the consumer expects. Concerning the increase of protein, this must be evaluated with caution. Since, depending on the goal it can bring benefits, but its excess can overwhelm renal function and impair calcium absorption. Thus, the nutritional education of consumers is an important aspect when incorporating this type of food to the diet.

\section{Acknowledgements}

To Faculdade Municipal Professor Franco Montoro (Mogi Guaçu-Brazil) for the technical support.

\section{References}

[1] D. C. Malta, A.S. Cezário, O.L. Morais Neto, and J.B. Silva Jr. "A construção da vigilância e prevenção das doenças crônicas não transmissíveis no contexto do Sistema Único de Saúde”. Epidemiol Serv Saúde.vol.15, n. 3, pp.47-65, 2006.

[2] L. Cordian, S.B. Eaton, A.Sebastian, N.Mann, S.Lindeberg, B.A. Watkins, J.H. O'Keefe, J.H. Brand-Miller. "Origins and evolution of the Western diet: health implications for the $21 \mathrm{st}$ century". Am. J. Clin. Nutr., vol. 81, n. 2, pp. 341-354, 2005.

[3] L.M.A. Diaz "Validação de um instrumento de avaliação do comportamento de consumidor adulto com sobrepeso/obesidade frente às informações nutricionais dos rótulos dos alimentos. Monographic. University of Brasília, Brasília, Brazil, 2006.

[4] M.M. Ribeiro; et al. "Estudo de mercado de iogurte da cidade de Belo Horizonte" Rev Ceres, vol.57, n.2, pp.151, 2010.

[5] E.A.F. Nilson, P.C. Jaime, D.O.Resende "Iniciativas desenvolvidas no Brasil para a redução do teor de sódio em alimentos processados" Revista Panamericana Salud Publica, vol.34, n.4, pp.287-292, 2012.

[6] Agência Nacional de Vigilância Sanitária - ANVISA. "Rotulagem Nutricional Obrigatória: Manual de Orientação aos Cosnumidores" Brasília, 2001.
[7] A.J. Paiva, and P. Henrique. "Adequação da Rotulagem de Alimentos Diet e Light ante a Legislação Específica.” Rev Baiana Saúde Publ., 2005.

[8] S.S. MACHADO et al. "Comportamento dos consumidores com relação à leitura de rótulos de produtos alimentícios." Alimentos e Nutrição, v.17,n.1,pp.97-103,2006.

[9] C.R. Aquino, and T.S. PHILIPPI. "Consumo Infantil de alimentos Industrializados e Renda Familiar na Cidade de São Paulo”. Rev de Saúde Públ., v.36, n.6, pp.655, 2002.

[10] D. GONZÁLEZ-CASTELL, et al. "Alimentos Industrializados em la Dieta de los pré-escolares mexicanos." Saúde Pública de México, v.49, n.5, pp.346, 2007.

[11] Agência Nacional de Vigilância Sanitária - ANVIAS. "Rotulagem nutricional obrigatória: Manual de Orientação aos Consumidores - Educação para o Consumo Saudável." Brasília, 2008.

[12] M.M. Braga, E.S. Abreu, and D.M. Chaud "Avaliação dos rótulos de alimentos diet e light comercializados em um empório da cidade de São Paulo (SP)". Revista Simbio-Logias, vol.4, n.6,2011.

[13] P.P.C. Garcia, and L.P.S. Carvalho "Análise da rotulagem nutricional de alimentos diet e light". Ensaios e Ciência. Ciências Biológicas, Agrárias e da Saúde”, vol.15, n.4, 2011.

[14] M.C.C. Câmara, C.L.C., Marinho, and M.C.R. Guiliam "Análise crítica da rotulagem de alimentos diet e light no Brasil" Caderno Saúde Coletiva, vol. 16, n.1, pp.35 - 52, 2008.

[15] S.M.L. Freitas "Alimentos com alegação Diet ou Light: Definições, Legislação e Implicações no Consumo". $1^{\text {st }}$. ed. São Paulo: Editora Atheneu,2005.140 p.

[16] C.C. Meira et al. "Estado nutricional e consumo de alimentos diet e light entre adolescentes de escola privada do município de João Pessoa -PB" Ensaios e Ciência: C. Biológicas, Agrárias e da Saúde, vol. 14,n 1,pp.65-81,2010.

[17] C.C. Santos et al. "Avaliação do Conhecimento da População em relação aos Alimentos Diet e Light". Revista Nutrire, vol. 38, pp. 80, 2013.

[18] T.R. Laurindo, R.R. Maldonado, and D. Oliveira "Percepção da população da Região de Mogi Guaçu sobre conceitos básicos relacionados a alimentos diet e light”. In: XII CONGRESSO BRASILEIRO DE CIÊNCIA E TECNOLOGIA DE ALIMENTOS (CBCTA), 2012, Campinas/SP, Brazil.

[19] B.R. Marins, I.S. Araújo, and S.C. Jacob "A propaganda de alimentos: orientação, ou apenas estímulo ao consumo?" Ciência \& Saúde Coletiva, vol.16, n.9, pp.3873-3882, 2011.

[20] E.Z.Giacoboo, T. Graff, and S.M.D. Bosco “ Nível de conhecimento sobre rotulagem de alimentos por consumidores do Município de Doutor Ricardo/RS" Revista Destaques Acadêmicos, vol.1, n.3, 2009.

[21] R.N.G. Montilla, J.M.Aldrighi, and M.F.N. Marucci "Relação cálcio/proteína da dieta de mulheres no climatério" Revista da Associação Médica Brasileira, vol.50, n.1, pp. 54-54, 2004.

[22] T.A.A. Silvia et al. " Sarcopenia Associada ao Envelhecimento: Aspectos Etiológicos e Opções Terapêuticas" Revista Brasileira Reumatologia, vol.46, n.6, pp. 391-397, 2006. 
[23] C.F. Sampaio, and M.V.C. Guedes "Processo de enfermagem como estratégia no desenvolvimento de competência para autocuidado" Acta Paul Enferm., vol. 25, pp.96-103, 2012.

[24] M.C.B. Molina et al. "Hipertensão arterial e consumo de sal em população urbana". Revista Saúde Pública, vol.37, n.6, pp.743-750, 2003.
[25] G.S. Mira, H.Graft, L.M.B. Cândido "Visão retrospectiva em fibras alimentares com ênfase em beta-glucanas no tratamento do diabetes". Braz. J. of Pharm. Sci., vol.45, n.1, 2009. 